\title{
Wheat Line "Selection 212" A Source of Broad Spectrum Resistance to Leaf Rust Pathotypes
}

\author{
Omkar M. Limbalkar ${ }^{1 *}$, J.B. Sharma ${ }^{1}$, S.K. Jha ${ }^{1}$, Mandeep Singh ${ }^{1}$, \\ Pandurang R. Divte ${ }^{2}$, N. Mallick ${ }^{1}$, M. Niranjana ${ }^{1}$ and $\operatorname{Vinod}^{1}$ \\ ${ }^{1}$ Division of Genetics, ${ }^{2}$ Division of Plant Physiology, ICAR-Indian Agricultural Research \\ Institute, New Delhi 110012, India \\ *Corresponding author
}

\section{A B S T R A C T}

\section{Keywords}

Selection 212,

Multipathotype testing, Wheat leaf rust, Broad spectrum resistance

Article Info

Accepted:

14 December 2018

Available Online:

10 January 2019
A leaf rust resistant stock 'Selection212' was assessed for resistance against array of leaf rust pathotypes and identified to be a source of resistance to all these pathotypes. The resistant stock Selection212including two susceptible checks Agra Local and Kharchia local were evaluated against 16 pathotypes of leaf rust, Puccinia triticina $(P t)$ pathogen. The Selection 212 showed high degree of broad spectrum resistance at seedling stage to diverse pathotypes of leaf rust pathogen in India and effective at adult plant stage against two most prevalent pathotypes 77-5 of leaf rust and pathotype $40 \mathrm{~A}$ of stem rust. Selection 212 was found resistant to leaf rust pathotypes, 12-3, 12-4, 77, 77A, 77A-1, 77-3, 77-5, 77-6, 77-7, 77-8, 77-10, 104-1, 104-4,106, 107-1 and 108. Some of the pathotypes like 77-7, 77-8 and 77-10 are known to have virulence against important resistance genes like $\operatorname{Lr} 9, \operatorname{Lr} 19$ and $\operatorname{Lr} 28$. Therefore, Selection 212 seems to be a source of broad spectrum resistance for leaf rust and can be used for further investigation by molecular studies, so that resistance can be exploited for marker assisted wheat breeding.

\section{Introduction}

Wheat is a major staple food crop being consumed by 30 percent population of the world (Eversole et al., 2014) and is grown in all the continents. Globally wheat is grown on 219.70 million hectares' area with production of $755.2 \mathrm{mt}$ (Source: USDA, 2017), while in India cultivated on an area of 30.60 million hectares with production of $98.61 \mathrm{mt}$, with highest ever productivity of $3.22 \mathrm{t} / \mathrm{ha}$ according to $3^{\text {rd }}$ advance estimate (2017-18) of government of India. In view of growing population, we need higher food grain yield. The yield can be increased through enhancing productivity or reducing the losses caused by biotic and abiotic stresses. Among several biotic stress causing damage to wheat crop, three rust diseases i.e. leaf, stem and stripe rust, are the most prevalent and reported from all wheat growing countries (Roelfs et al., 1992). The rusts are known to reduce wheat 
production worldwide and causing significant losses to the yield. Among three wheat rusts, leaf rust (Puccinia triticina. f. sp. tritici Eriks) is most common in all wheat growing regions (Roelfs et al., 1995). Leaf rust could result in major losses due to higher number of infection cycles during crop growth in congenial environment. They have potential to cause yield losses up to 50 percent, if infection starts at early growth stage (Huerta-Espino et al., 2011). There are few leaf rust resistance genes which have been commercially exploited so far in Indian cultivar are $L r 1, L r 3, L r 9, L r 10$, Lr13, Lr14a, Lr17, Lr19, Lr23, Lr24, Lr26, Lr28 and Lr34 (Bhardwaj et al., 2010) but only $L r 24$ is all plant stage resistance gene for which virulence is not known in India. However, virulence already has been reported for $L r 24$ in some countries (Singh, 1991). The frequent emergence of new pathotypes in wheat rust necessitates search of new broad spectrum resistance sources to be utilized in breeding program.

Efforts have been made for the search of novel and effective sources of resistance by geneticists and plant breeders throughout the world, in this regard till date 79 leaf rust resistance $(L r)$ genes were identified (McIntosh et al., 2017; Qureshi et al., 2018). The present study is a step towards identifying another novel broad spectrum resistance gene by screening genetic stock"Selection 212 "with different pathotypes of leaf rusts pathogen at seedling stage.

\section{Materials and Methods}

\section{Plant material}

Thewheat line Selection212 $(2 \mathrm{n}=42)$, a homoeologous recombinant of wheat ( $T$. aestivum) and rye (Secale cereale), was developed at the Division of Genetics, IARI, New Delhi (Singh, 1991). Susceptible cultivars used in current study were Agra
Local and Kharchia Local,a highly susceptible genotypes against Indian pathotypes of all three rust at seedling as well as adult stage (Mehta, 1929), hence were used as control as well as for multiplication of rust inoculum.

\section{Pathogen}

The single spore culture inoculum of 16 pathotypes of Puccinia triticina. f. sp. tritici Eriks $(P t)$ procured from IIWBR, Regional Station, Flowerdale, Shimla during 2016-17 and 2017-18 were used for present study. In addition, a stem rust, Puccinia graminis f.sp. tritici (Pgt) pathotype 40A was used for screening at adult plant stage.

\section{Multiplication of rust inoculum}

Urediniospore of pathotypes was multiplied in glass house on Agra local (Joshi et al., 1988). Susceptible host, Agra Local was sown in 4" plastic pots filled with thoroughly mixed garden soil. Seeds were sown and irrigated for proper germination. After 10 days, seedlings were ready for inoculation. Rust inoculum was mixed with non-toxic talcum powder and applied on the surface of leaves. After inoculation water was sprayed on seedlings so as to deposit small dew droplets on the leaves. The inoculated seedlings were transferred to humidity chamber for next 48 hours. After incubation of 48 hours, seedlings were taken out and transferred to the glasshouse benches for sporulation. The sporulation appeared after 12-13 days of inoculation under optimum conditions. Urediniospore inoculum was collected every alternate day by gently tapping and used for multipathotype testing.

\section{Multipathotype test}

Selection212 along with susceptible genotype Agra Local and Kharchia Local were sown in 4 " pot for evaluation with different pathotypes 
of leaf rust. 10 days old seedlings were inoculated by freshly multiplied urediniospores $P t$ and $P g t$ pathotypes separately as water suspension using a drop of Tween 20 (Polysorbate 20) as surfactant. The inoculated seedlings were kept in humidity chamber for 48 hours and then shifted to glass house benches. The infection types were recorded after 12 days of inoculation based on 0-4 scale of standard classification given by Stakman et al., (1962). The infection type 0,; 1 and 2 were classified as resistant reaction while infection types 3 and 4 were grouped as susceptible.

\section{Results and Discussion}

The resistant stock Selection212 as well as susceptible cultivars Agra Local and Kharchia Local were screened with 16Pt pathotypes including 10 pathotypes not tested earlier and infection types were recorded on these lines are presented in Table 1. 'Selection212' expressed resistant infection types against all 16 pathotypes tested with, ranging from ' 0 ;' to ' $\mathrm{X}^{-}$'. In contrast, Agra Local and Kharchia Local showed susceptible reaction with infection type ranging from ' 3 ' to ' 3 ' against all these pathotypes used in the study (Figure 1). Results suggested that leaf rust resistance gene in 'Selection212' showed hypersensitive reaction at seedling stage to different pathotypes of leaf rust indicating its effectiveness and broad-spectrum of resistance.

Selection212 and Agra Local were tested at adult plant stage by inoculating the flag leaf and penultimate leaf with $P t$ pathotype 77-5 and Pgt pathotypes 40A. Selection212 expressed high degree of hypersensitive resistant response in contrast to highly susceptible response by check Agra Local with both the pathotypes (Figure 2). The effectiveness of Selection212 at adult plant stage suggests its effectiveness at all plant stage.
The result of multipathotype test indicates that Selection212 is source of broad spectrum resistance to leaf rust pathotypes. Sharma and Singh in 2000 assessedSelection212 with 25 leaf rust and 20 stem rust pathotypes and found Selection212 to be resistant to all pathotypes. In present study, Selection212 was found to be resistant to additional $10 P t$ pathotypes.

The leaf rust resistance genes $L r l, L r 3, L r 9$, Lr10, Lr13, Lr14a, Lr17, Lr19, Lr23, Lr24, $L r 26, L r 28$ and $L r 34$ are exploited so far in Indian cultivar (Bhardwaj et al., 2010). The avirulence/virulence pattern of these pathotypes according to Prasad et al., (2017) suggested that all these leaf rust resistance genes except $\operatorname{Lr} 24$ were susceptible to pathotypes 12-4, 77A, 77A-1, 77-6, 77-7, 77$8,77-10,104-1$ and 104-4 in other hand Selection212 were shown resistant reaction indicating its differential response against leaf rust pathotypes and could be a new source of resistance to leaf rust pathotypes.

The leaf rust resistance gene in Selection212 was located cytogenetically on chromosome 2B and named as LrSel212 (Sharma and Singh, 2001), out of $16 P t$ pathotypes in present study 10 pathotypes were not tested earlier and found avirulent against resistance genes like $\operatorname{Lr} 4,5,6,7,8,24,25,32,39,41$, 42, 45, 47 (Prasad et al., 2017) with only Lr25 (McIntosh,1988) and Lr45 (McIntosh et al., 1995) is derived from Secale cereale. But none of the resistance genes identified from avirulence pattern is located on chromosome 2B while leaf rust resistance gene in Selection 212 was reported earlier to be located on $2 \mathrm{~B}$ chromosome cytologically (Table 2 ).

The leaf rust resistance gene in Selection 212 was located cytogenetically on chromosome 2B and named as LrSel212 (Sharma and Singh, 2001), out of $16 P t$ pathotypes in present study 10 pathotypes were not tested 
earlier and found avirulent against resistance genes like $\operatorname{Lr} 4,5,6,7,8,24,25,32,39,41$, 42, 45, 47 (Prasad et al., 2017) with only Lr25 (McIntosh,1988) and Lr45 (McIntosh et al., 1995) is derived from Secale cereale. But none ofthe resistance genes identified from avirulence pattern is located on chromosome 2B while leaf rust resistance gene in Selection212was reported earlier to be located on $2 \mathrm{~B}$ chromosome cytologically.

The number of leaf rust resistance genes are already designated on chromosome $2 \mathrm{~B}$ are Lr13, Lr16, Lr23, Lr35 and Lr73 (Dycket al., 1966; Dyck and Samborski, 1968; McIntosh and Dyck, 1975; Kerber and Dyck, 1990; Park et al., 2014). Avirulence/virulence pattern (Prasad et al., 2017) for these resistance genes with 16 pathotypes used in study suggested that among the leaf rust resistance genes Lrl3andLrl6 have shown susceptibility to total 15 pathotypes used in study while Selection 212 has showed resistance to these pathotypes in the present multipathotype testing. Hence presence of Lrl3 and Lrl6 in Selection 212 can be ruled out.

Similarly, $\operatorname{Lr} 23$ has made ineffective by $6 \mathrm{Pt}$ pathotypes (77-5, 77-6, 77-7, 77-10, 104-1 and 104-4) to which Selection 212 has shown resistant response thereby ruling out the presence of $L r 23$ in Selection212. The leaf rust resistance genes $\operatorname{Lr} 13, \operatorname{Lr} 16, \operatorname{Lr} 23$ were found to be susceptible against pathotype 77-5 whereas Selection212 was resistant (Sharma and Singh, 2000). The resistance genes Lr35 and $L r 73$ are adult plant resistance (APR) genes and effective only at adult stage of the plant growth and seedlings of plants with these genes shows susceptibility but Selection212 has seedling resistance (which is effective throughout the plant life) to all the pathotypes tested with earlier and in present study again ruling out the presence of these genes in Selection212. The above-mentioned logics of absence of Lr13, Lr16, Lr23, Lr35 and $L r 73$ in Selection212 suggest a strong case for identification and mapping of a new leaf rust resistance gene named LrSel212. Pathotypes 77-5 apart from being most prevalent is also the most virulent that makes ineffective most of the $T$. aestivum originated seedling resistance genes for leaf rust like $\mathrm{Lr}$ $1,2 a, 2 b, 2 c, 3,10,11,13,14 b, 15,16,17,20$, 27+31, 30, 33, 49 (Prasad et al., 2017) indicating that the leaf rust resistance in Selection212 effective against pathotype 77-5 is different from the rust resistance genes susceptible to this pathotype.

The spectrum of infection types produced by Selection212 neither compares with any of the known resistance gene(s) present in differential lines used in the Indian differential sets nor can be explained by combination of more than one $T$. aestivum derived genes based on avirulence/virulence analysis of 16 pathotypes used in the study indicating that the leaf rust resistance in Selection212could be a new source of resistance.

Leaf rust pathotypes77-5 and 77-6 made ineffective important resistance genes like Lr13, Lr16, Lr23 and Lr35. However Selection 212 has been tested with pathotype 77-5 and 77-6 in current study exhibits resistance reaction against these pathotype suggesting its effectiveness to combat with new virulent pathotypes of leaf rust.

Therefore, to cope with dynamic nature of rust pathogen we need to broaden the genetic base of present cultivar by investigating new source of resistance. As Selection212 showing broad spectrum resistance to total 35 pathotypes of leaf rust including 10 new pathotypes in present studies and 25 pathotypes in previous study (Sharma and Singh, 2000), therefore Selection 212 could be effective source of broad spectrum resistance to leaf rust pathotypes. At the outset resistance in Selection212 was considered to be different from earlier report in case of leaf rust resistance. 
Table.1 Infection types on Selection212, Agra Local and Kharchia Local against 16pathotypes of leaf rust ( $P$. triticina) at seedling stage of plant growth at mean temperature range 20-280 C

0 (Immune); (Very resistant), 1(Resistant), 2(Moderately resistant), X (Mesosthetic), 3

(Moderately susceptible), '=':Uredia much smaller than typical and at the low limit for the infection type, '-': Uredia smaller than normal, ' $N$ ' indicates more than usual degree of necrosis

\begin{tabular}{|c|c|c|c|c|}
\hline S. No. & Pathotypes & Selection212 & Agra Local & Kharchia Local \\
\hline 1 & $12-3$ & $\mathbf{X}^{-}$ & $33^{+}$ & $3^{+}$ \\
\hline 2 & $12-4$ & $\mathbf{1}^{-}$ & $3^{+}$ & $33^{+}$ \\
\hline 3 & 77 & $\mathbf{X}^{=}$ & $3^{+}$ & $3^{+}$ \\
\hline 4 & $77 \mathrm{~A}$ & ; & 3 & $33^{+}$ \\
\hline 5 & $77 \mathrm{~A}-1$ & ;1 & $33^{+}$ & $3^{+}$ \\
\hline 6 & $77-3$ & ;1 & $3^{+}$ & $3^{+}$ \\
\hline 7 & $77-5$ & $; \mathbf{1}^{+}$ & $3+$ & $3+$ \\
\hline 8 & $77-6$ & $\mathbf{X}^{=}$ & $3^{+}$ & $3^{+}$ \\
\hline 9 & $77-7$ & $\mathbf{X}^{-}$ & $X$ & $33^{+}$ \\
\hline 10 & $77-8$ & $; \mathbf{1}^{=}$ & 3 & $3^{+}$ \\
\hline 11 & $77-10$ & ;1 & $33^{+}$ & $33^{+}$ \\
\hline 12 & $104-1$ & $; \mathbf{1}^{\mathrm{N}}$ & $3^{+}$ & $3+$ \\
\hline 13 & $104-4$ & ;1 & $3^{+}$ & $33^{+}$ \\
\hline 14 & 106 & 0; & $3^{+}$ & 3 \\
\hline 15 & $107-1$ & ;1- & 3 & 3 \\
\hline 16 & 108 & ;1- & 3 & 3 \\
\hline
\end{tabular}

Table.2 Avirulence pattern of different resistance genes with their location, source and reaction types

\begin{tabular}{|c|c|c|c|c|}
\hline$L r$ gene & Location & Source & IT & References \\
\hline$L r 4-8$ & abandoned & & & \\
\hline Lr 24 & 3DL & Th.ponticum & 0 ; to 1 & McIntosh et al., 1976 \\
\hline Lr 25 & 4BS & Secale cereale & $0 ;, 1,12$ & McIntosh, 1988 \\
\hline Lr 32 & $3 \mathrm{D}$ & T. tauschii & $1^{+} 2^{-}$ & Kerber, 1987 \\
\hline Lr 39 & 2DS & T. tauschii & $12^{-}$ & Raupp et al., 2001 \\
\hline $\operatorname{Lr} 41$ & $1 \mathrm{D}$ & T. tauschii & ; & Cox et al., 1994 \\
\hline $\operatorname{Lr} 42$ & 1D & T. tauschii & ; to $; 1$ & Cox et al., 1994 \\
\hline $\operatorname{Lr} 45$ & $2 \mathrm{AS}$ & Secale cereale & $; 12$ & McIntosh et al., 1995 \\
\hline Lr 47 & 7AS & Ae. speltoides & ; & Dubcovsky et al., 1998 \\
\hline LrSel212 & 2B & Secale cereale & $\mathrm{X}^{-}$ & Sharma and Singh, 2001 \\
\hline
\end{tabular}


Fig.1

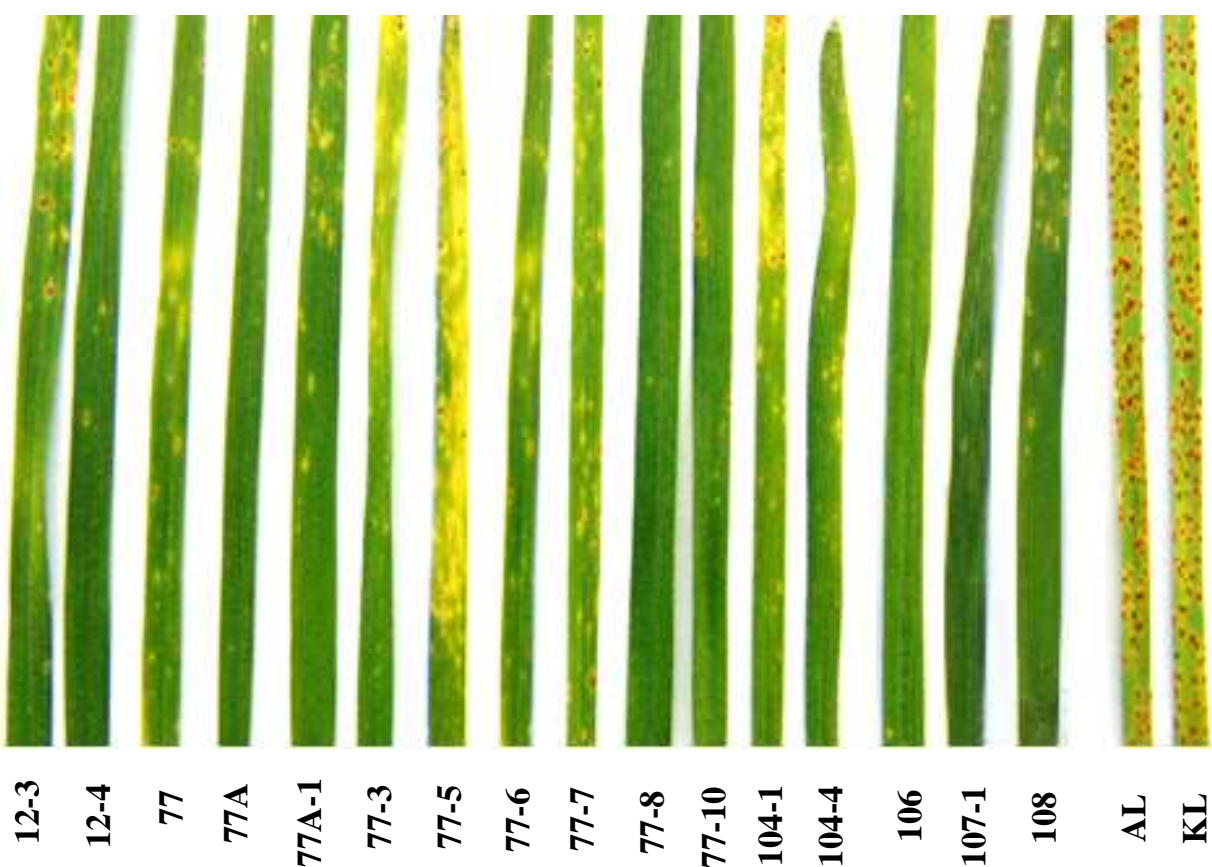

Figure 1 Infection types on Sel.212, Agra Local at seedling stage against leaf rust pathotypes of different groups

Fig.2

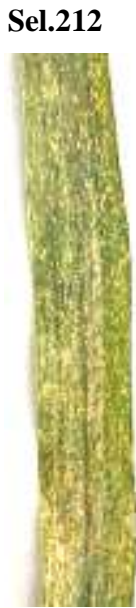

Reaction with 77-5

AL

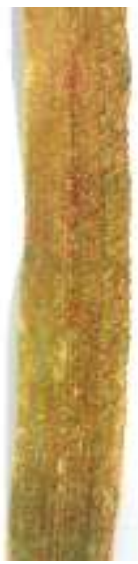

Adult

dult plant response of parental lines, Selection212 and Agra Local against leaf and stem rust pathotypes 77-5 and 40A respectively in field condition
AL

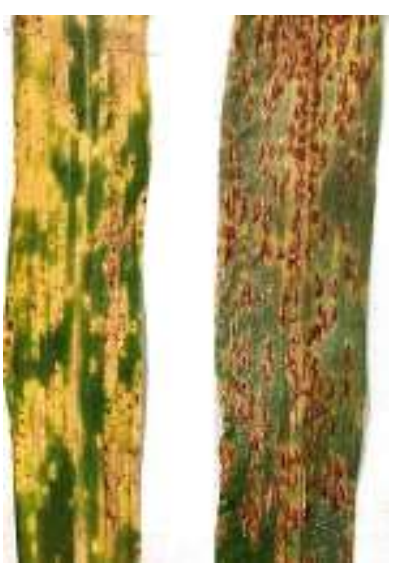

Reaction with $40 \mathrm{~A}$
The previous study suggests that Selection 212 which is derivative of wheat rye recombinant (Singh, 1991), so far only resistance genes like $L r 25,26$ and $L r 45$ for leaf rust have been reported from rye (McIntosh, 1995; 2017). Hence, to exploit the genetic potential of rye 
(Secale cereale) for rust resistance need more investigation by genetic and molecular studies to identify genetic nature of rust resistance and molecular markers linked to gene of interest. Therefore, Selection212 seems to be a source of broad spectrum resistance for leaf rust and can be used for further investigation by molecular studies, so that resistance can be exploited for marker assisted wheat breeding.

\section{Acknowledgements}

OML is grateful to Division of Genetics and Post-Graduate School, ICAR-Indian Agricultural Research Institute, New Delhi for granting Junior Research Fellowship. Authors are thankful to the Indian Institute of Wheat \& Barley Research, Flower dale, Shimla for providing pure inoculum of leaf and stem rust pathotypes.

\section{References}

Agricultural Statistics Division, Directorate of Economics \& Statistics, Department of Agriculture, Cooperation and Farmers Welfare (2018) Third Advance Estimates of Production of Food grains for 2017-18.

Bhardwaj, S.C., Prashar, M., Jain, S.K., Kumar, S. and Sharma, Y.P. (2010) Physiologic specialization of Puccinia triticina on wheat (Triticum species) in India. Indian $J$ AgricSci 80:805-811.

Cox, T.S., Raupp, W.J. and Gill, B.S. (1994) Leaf rust-resistance genes $\mathrm{Lr} 41, \mathrm{Lr} 42$ and $\mathrm{Lr} 43$ transferred from Triticum tauschii to common wheat. Crop Science 34:339-343.

Dubcovsky, J., Lukaszewski, A.J., Echaide, M., Antonelli, E.F. and Porter, D.R. (1998) Molecular characterization of two Triticum speltoides interstitial translocations carrying leaf rust and greenbug resistance genes. Crop science 38(6):1655-60.

Dyck, P.L. andSamborski, D.J. (1968)Genetics of resistance to leaf rust in the common wheat varieties Webster, Loros, Brevit, Carina, Malakof and Centenario. Canadian journal of Genetics and Cytology10:7-17.

Dyck, P.L., Samborski, D.J., Anderson, R.G.
(1966). Inheritance of adult plant leaf rust resistance derived from the common wheat varieties Exchange and Frontana. Canadian Journal of Genetics and Cytology8:665671.

Eversole, K., Feuillet, C., Mayer, K.F.X. and Rogers, J. (2014) Slicing the wheat genome. Science 345(6194): 285-287.

Huerta-Espino, J., Singh, R.P., German, S., McCallum, B.D., Park, R.F., Chen, W.Q., Bharadwaj, S.C. and Goyeau, H. (2011) Global status of wheat leaf rust caused by Puccinia triticina. Euphytica, 179:143-160.

Joshi, L.M., Singh, D.V. and Srivastava, K.D. (1988) Manual of wheat diseases. Malhotra Publication House, New Delhi, 75 pp.

Kerber, E.R. (1987). Resistance to leaf rust in hexaploid wheat, $L r 32$, a third gene derived from Triticum tauschii. Crop Science 27, 204-206.

Kerber, E.R., Dyck, P.L. (1990) Transfer to hexaploid wheat of linked genes for adult plant leaf rust and seedling stem rust resistance from an amphidiploid of Aegilopsspeltoides x Triticum monococcum. Genome 33:530-537.

McIntosh, R.A. (1988). Catalogue of gene symbols for wheat. Proceedings of the Seventh International Wheat Genetics Symposium Vol 2. (Eds TE Miller and RMD Koebner.) pp. 1225-1323.

McIntosh, R.A. (1988). Catalogue of gene symbols for wheat. Proceedings of the Seventh International Wheat Genetics Symposium Vol 2. (Eds TE Miller and RMD Koebner.) pp. 1225-1323. (Institute of Plant Science Research: Cambridge, UK.)

McIntosh, R.A., Dubcovsky J., Rogers, W.J., Morris, C. and Xia, X.C. (2017) Catalogue of gene symbols for wheat: 2017 Supplement.

McIntosh, R.A., Dyck, P.L. (1975) Cytogenetical studies in wheat VII. Gene Lr23 for reaction to Puccinia reconditain Gabo and related cultivars. Australian Journal of Biological Sciences28:201-211.

McIntosh, R.A., Dyck, P.L. and Green, G.J. (1976). Inheritance of leaf rust and stem rust resistances in wheat cultivars Agent and Agatha. Australian Journal of Agricultural Research, 28: 37-45. 
McIntosh, R.A., Friebe, B., Jiang, J. and Gill, B.S. (1995) Cytogenetical studies in wheat XVI. Chromosome location of a new gene for resistance to leaf rust in a Japanese wheatrye translocation line. Euphytica 82(2):1417.

McIntosh, R.A., Wellings, C.R. and Park, R.F. (1995) Wheat Rusts-An Atlas of Resistance Genes. Kluwer Academic Publishers, Dordrecht, Boston, London.p.200.

Mehta, K.C. (1929) Annual recurrence of rusts on wheat in India. (Presidential Address) Proc Indian SciCongr 16:199-223.

Park, R.F., Mohler, V., Nazari, K. and Singh, D. (2014) Characterisation and mapping of gene $\operatorname{Lr} 73$ conferring seedling resistance to Puccinia triticina in common wheat. Theor Appl Genet 127:2041.

Prasad, P., Bhardwaj, S.C., Gangwar, O.P., Kumar, S., Khan, H., Kumar, S. and Sharma, T.R. (2017) Population differentiation of wheat leaf rust fungus Puccinia triticina in South Asia. Curr Science 112(10): 2073.

Qureshi, N.,Bariana, H., Kumran, V.V., Muruga, S., Forrest, K.L., Hayden, M.J. and Bansal, U. (2018) A new leaf rust resistance gene Lr79 mapped in chromosome 3BL from the durum wheat landrace Aus26582. TheorAppl Genet 131(5):1091-8.

Raupp, W.J., Brown-Guedira, G.L. and Gill, B.S. (2001) Cytogenetic and molecular mapping of the leaf rust resistance gene Lr39 in wheat. Theoretical and applied genetics 102(2-3):347-52.

Roelfs, A.P. and Bushnell, W.R. (1995) The Cereal Rusts Volume II. Diseases, Distribution, Epidemiology, and Control.
Orlando, FL, USA: Academic Press, 371402.

Roelfs, A.P., Singh, R.P. andSaari, E.E. (1992) Rust diseases of wheat: Concepts and methods of disease management. CIMMYT, Mexico, D.F., Mexico.

Sharma, J.B. and Singh, D. (1999) Analysis of linked leaf and stem rust resistance in wheat-rye recombinant Selection212. Ind $J$ Genet 59:391-395.

Sharma, J.B. and Singh, D.(2000) Assessment of Selection212- a wheat-rye recombinant line for resistance to leaf rust and stem rust. Ind J Genet 60:5-14.

Sharma, J.B. and Singh, D. (2001). Chromosome location of leaf rust and stem rust resistance genes in a wheat-rye recombinant line Selection212. Ind J Genet 61:16-18.

Singh, D. (1991) Wheat rye recombinant resistant to all three rusts of wheat. Ann Wheat Newsl 37:68.

Singh, R.P.(1991) International Maize and Wheat Improvement Center. Pathogenicity variations of Puccinia recondita f. Sp. Tritici and P. Graminis f. Sp. Tritici in wheat growing areas of Mexico during 1988 and 1989. Plant Dis 75:790-794.

Stakman EC, Stewart DM, Loegering WQ (1962) Identification of physiological races of Puccinia graminis var. tritici. Agricultural Research Service E-617, United States Department of Agriculture, Washington DC.

USDA-United States Department of Agriculture (2017) World Agricultural Production Foreign Agricultural Service Circular Series WAP 12-17December 2017.

\section{How to cite this article:}

Omkar M. Limbalkar, J.B. Sharma, S.K. Jha, Mandeep Singh, Pandurang R. Divte, N. Mallick, M. Niranjana and Vinod. 2019. Wheat Line "Selection212" A Source of Broad Spectrum Resistance to Leaf Rust Pathotypes. Int.J.Curr.Microbiol.App.Sci. 8(01): 2012-2019. doi: https://doi.org/10.20546/ijcmas.2019.801.211 